TITLE:

\title{
Vegetation succession on Mt. Kenya in relation to glacial fluctuation and global warming
}

$\operatorname{AUTHOR}(\mathrm{S})$ :

Mizuno, Kazuharu; Fujita, Tomohiro

\section{CITATION:}

Mizuno, Kazuharu ... [et al]. Vegetation succession on Mt. Kenya in relation to glacial fluctuation and global warming. Journal of Vegetation Science 2013, 25(2): 559-570

\section{ISSUE DATE:}

2013-04-19

URL:

http://hdl.handle.net/2433/197328

\section{RIGHT:}

This is the peer reviewed version of the following article: Mizuno, K.. Fujita, T. (2014), Vegetation succession on Mt. Kenya in relation to glacial fluctuation and global warming. Journal of Vegetation Science, 25: 559-570, which has been published in final form at http://dx.doi.org/10.1111/jvs.12081; This is not the published version. Please cite only the published version.; この論文は出版社版でありません。引用の際には出版社版をご確認ご利用ください。 
Vegetation succession on Mt. Kenya in relation to glacial fluctuation and global warming

Kazuharu Mizuno \& Tomohiro Fujita

Mizuno, K. (corresponding author, mizuno@jambo.africa.kyoto-u.ac.jp) \& Fujita, T. (tomohiro@jambo.africa.kyoto-u.ac.jp): Department of African Area Studies, Graduate School of Asian and African Area Studies, Kyoto University, 46 Shimoadachi-cho, Yoshida, Sakyo-ku, Kyoto 606-8501, Japan.

\section{Abstract}

Question: 1) How has the plant community responded to recent glacial retreat? 2) Has the recent glacial retreat been affected by increases in temperature? 3) How have the number of plant clumps and the proportion of vegetation cover changed with the distance from the glacier edge (i.e., till age)?

Location: From Tyndall Tarn to the foot of Tyndall Glacier of Mt. Kenya ( $0^{\circ} 6^{\prime} \mathrm{S}, 3^{\circ} 18^{\prime}$ E), Kenya.

Methods: The topography, soils, vegetation, and glacial distribution around the Tyndall Glacier of Mt. Kenya were investigated from 1992 to 2011. The effect of glacial retreat on the rate of movement of the leading edge (upper distribution limit) of plant species was examined. The distribution of vegetation was examined in a permanent plot that was surveyed in 1996 and 2011. The effects of temperature variation on glacial retreat 
were assessed by a least squares regression model.

Results: Tyndall Glacier retreated at a rate of $\sim 3 \mathrm{~m} \mathrm{year}^{-1}$ from 1958 to 1997 . The rate increased to 7-15 m year-1 between 1997 and 2011. The leading edge of Senecio keniophytum, the first pioneer species to establish after glacial retreat, advanced with glacial recession. It was sparse in 1996. By 2011, the number of clumps and proportion of cover had increased. Clump size was affected by distance from the glacier edge (i.e., till age) in areas of recent deglaciation but not in deglaciated areas older than 15 years. Monthly mean minimum temperature at Mt. Kenya increased by $>2^{\circ} \mathrm{C}$ from 1963 to 2011 and glacial retreat was related to increase in monthly mean minimum temperature. Conclusion: The glaciers on Mt. Kenya have diminished rapidly in recent years, and pioneer plant species have advanced in response. The movements of some species do not appear to be directly spatially related to glacial retreat but may be related to increases in air temperature, soil development, seed dispersal limitation, and interval of masting. Recent unusually high temperatures and precipitation also likely caused the blooming during atypical seasons of some species.

Keywords: Glacier retreat; Global warming; Large woody rosette plants; Phenology; Pioneer species; Tyndall Glacier

Nomenclature: Coe (1967)

\section{Introduction}

Large changes are taking place on the high, glacier-covered mountains of Africa. The only African mountains still capped by glaciers are Mt. Kilimanjaro, Mt. Kenya, and Mt. Rwenzori. However, the retreat rate of theses glaciers has accelerated (Hastenrath $1984,1997,2005,2008)$ and are expected to disappear in the near future. 
Numerous studies have been carried out on the dynamics of the glaciers of Mt. Kenya (Troll \& Wien 1949; Charnley 1959; Hastenrath 1984, 1991, 2005; Kruss \& Hastenrath 1983). Many of these studies have examined glacial fluctuations and deposits (Mahaney 1984, 1989, 1990; Mahaney \& Spence 1989). Although plant succession has been well documented on glacier forelands in North America (Jones \& del Moral 2005), Scandinavia (Robbins \& Matthews 2009), other Arctic locations (Hodkinson et al. 2003), and the European Alps (Niederfriniger-Schlag \& Erschbamer 2000; Raffl \& Erschbamer 2004; Raffl et al. 2006a; Garbarino et al. 2010), little research has examined primary succession following glacial retreat on high, tropical mountains.

Worldwide, most studies have described vegetation changes on differently aged moraines and have chronicled centuries of change (Okitsu et al. 2004; Jones \& del Moral 2005; Raffl et al. 2006b; Mori et al. 2008). However, few studies have involved real-time recordings of glacier recession and plant advance, in contrast to studies of community succession based on chronosequences and historical records of previous extensions of glaciers (Nagy \& Grabherr 2009). Most studies have found that time, expressed as till age, is the main factor controlling species distributions (Whittaker 1987; Matthews 1992; Caccianiga et al. 2001). Previous research has demonstrated that succession requires several hundred years to reach the climax stage of alpine grasslands on ground moraines (Raffl \& Erschbamer 2004). Low-cover pioneer communities grow on $20^{\text {th }}$-century deposits, whereas high-cover communities occur mainly on already stabilized moraines that date back to the $19^{\text {th }}$ century (Caccianiga \& Andreis 2004). Microbial functional diversity reaches stability within 50 years' succession (Tscherko et al. 2003). In the foreland of the Coleman Glacier, species richness and diversity were highest during early succession on small scales and during late succession on larger 
scales (Jones \& del Moral 2005). However, in addition to till age, substratum stability may strongly influence vegetation patterns around glaciers on high, tropical mountains (Mizuno 1998, 2005a, 2005b). By examining patterns of larch establishment, Garbarino et al. (2010) found that the most influential factors determining stand density and age were proximity to the glacier terminus and seed sources as well as litter cover and elevation.

Coe (1967) described the distribution of vegetation, the colonization by plants, and the distribution of individual plant species on slopes below glaciers on Mt. Kenya. Spence (1989) analyzed the advance of plant communities in response to the retreat of the Tyndall and Lewis Glaciers from 1958 to 1984, and Mizuno (2005a, 2005b) examined the response of plant communities to more recent glacial retreats in 1992, 1994, 1996, 1997, and 2002.

In 2009, a previously unreported species was found in the outer areas of old glacial flow paths. Thus, some plant species have advanced regardless of glacial retreat. However, no studies have examined vegetation succession due to both recent glacial retreat and global warming, and their relationships have not been fully clarified.

In the present study, the following questions were investigated: 1) How has the plant community responded to recent glacial retreat? 2) Has the recent glacial retreat been affected by increases in temperature? 3) How have the number of plant clumps and the proportion of vegetation cover changed with the distance from the glacier edge (i.e., till age)? It was predicted that the invasion of new species to the study area in 2009 was affected by increases in temperature and that the atypical timing of the blooming of some species has been influenced by recent unusual temperatures or precipitation. 


\section{Methods}

Study area - age, climate, and vegetation

The main study area was around Tyndall Glacier but, for comparison, the Lewis Glacier on Mt. Kenya and the glaciers on Mt. Kilimanjaro were also investigated.

Mt. Kenya is an isolated, extinct, denuded volcano that lies on the equator $\left(0^{\circ} 6^{\prime} \mathrm{S}\right.$, 37018' E), approximately 150 km north-northeast of Nairobi. The highest peak, Batian, is $5199 \mathrm{~m}$ above sea level. The mountain was formed between 3.1 and 2.6 million years ago (Bhatt 1991), and the volcanic plug has been dated to 2.64 million years ago (Mahaney 1990). Rocks of the volcanic massif consist of basalt, phonolite, kenytes, agglomerates, trachyte, and syenite (Mahaney 1990; Bhatt 1991).

There were 18 glaciers on Mt. Kenya at the end of the $19^{\text {th }}$ century (Hastenrath 2008), but only a few, including the Lewis and Tyndall Glaciers, remain. Fluctuations in the sizes and movement of these glaciers have been recorded in detail (Hastenrath 1984, 1997, 2005, 2008; Mahaney 1990). Mahaney $(1984,1990)$ subdivided into the Tyndall advance (the Tyndall Moraine, ca. 900 yr BP) and the Lewis advance (the Lewis Moraine, ca. 100 yr BP), on the basis of several indirect measurements that included topographic position, weathering characteristics, and the degree of soil development (Spence \& Mahaney 1988; Mahaney 1989, 1990; Mizuno 1998, 2005a).

The elevations in East Africa at which the annual minimum, mean, and maximum temperatures of the free atmosphere are $0^{\circ} \mathrm{C}$ are approximately $3500 \mathrm{~m}, 4750 \mathrm{~m}$, and $6000 \mathrm{~m}$, respectively (Hastenrath 1991). Annual precipitation is about $2500 \mathrm{~mm} \mathrm{year}^{-1}$ 
at $2250 \mathrm{~m}$ on the southeastern slopes of Mt. Kenya and decreases to less than $1000 \mathrm{~mm}$ year $^{-1}$ at that altitude on the northern slope (Mahaney 1984; Hastenrath 1991). Annual rainfall is highest between 2500 and $3000 \mathrm{~m}$ on the south, west, and east slopes, and decreases towards the peak ( $<900 \mathrm{~mm}$ at $4500-4800 \mathrm{~m}$ ). Above $4500 \mathrm{~m}$, most precipitation falls as snow and hail.

The vegetation of Mt. Kenya has been classified into the Alpine Belt ( $>3600 \mathrm{~m}$ ), the Ericaceous Belt (3600-3400 m on the south slope, $2900 \mathrm{~m}$ on the north slope), and the Montane Forest Belt (<3400 m; Hastenrath 1984). The altitudinal distributions of Senecio keniodendron and Senecio keniensis (formerly S. brassica) are used to distinguish between the upper and lower alpine zones, although there is considerable overlap in their distribution (Hedberg 1951; Young and Peacock 1992). In the lower alpine zone, the tussock grasses S. keniensis and Lobelia keniensis occupy the wetter areas, and Alchemilla spp. predominate in dry areas. In the upper alpine zone, $S$. keniodendron is present up to $4500 \mathrm{~m}$ together with Carex monostachya, Agrostis spp., Carduus platyphyllus, Arabis alpina, Senecio keniophytum, and Lobelia telekii. In general, large woody rosette plants, including giant senecio (e.g., S. keniodendron) and giant lobelia (e.g., L. telekii), are characteristic of high, tropical mountain landscapes with large ranges in diurnal temperature (Hedberg 1964, 1968; Coe 1967; Smith \& Young 1987; Rehder et al. 1988; Young 1991; Rehder 1992).

Data collection

Measurement of topography and glacier

Topography, soils, vegetation, and location of the glacial edge in several years around 
the Tyndall Glacier of Mt. Kenya were investigated from 1992 to 2011. A topographic profile was created, with distance and surface inclinations measured using a laser rangefinder (TruPulse 200). At the glacial margins, latitude and longitude were recorded using a global positioning system (GPS) unit, and the distances from the foot of Tyndall Glacier to a large rock constituting the northern part of the Tyndall Tarn were measured using both a measuring tape and the laser rangefinder. The length, width, and thickness of the glacier were measured in the same way.

\section{Climate data}

Temperature and precipitation data were acquired from the Meteorological Department of Nairobi. These data were recorded at the Nanyuki Meteorological Station (1890 $\mathrm{m}$ in altitude, $0.03^{\circ} \mathrm{N}, 37.02^{\circ} \mathrm{E}$ ) on the north-northwest side of Mt. Kenya. Temperature data of the Mt. Kenya Global Atmosphere Watch (GAW) Station (3678 m in altitude, $-0.06^{\circ} \mathrm{N}, 37.30^{\circ} \mathrm{E}$ ) on the north side of Mt. Kenya were used for comparison with the data from Nanyuki. Because much of the data from the GAW Station were missing, data for months without missing data (July 2003, April 2004, and November 2005) were used to determine the temperature lapse rate. Based on comparisons between air temperature data at 1890 and $3678 \mathrm{~m}$, the temperature lapse rate at Mt. Kenya was determined to be $0.63^{\circ} \mathrm{C} / 100 \mathrm{~m}$ (July 2003: 0.64, April 2004: 0.62, May 2005: 0.63). This was used to estimate the temperature at $4500 \mathrm{~m}$ altitude in the study area.

Temperature was recorded to assess the freeze-thaw environment of the land surface using an air temperature sensor and a data logger in the vicinity of the glacier edge from 
31 August to 3 September 2011.

Soil profile

Typical soil profiles from various till ages (years after the disappearance of the glacier) were determined using soil profile data observed in 1992-2009. Till age (years) of the site was estimated from the glacial retreat rate and the distance from the glacier edge. In each soil profile, the texture, structure, and color of the soil were determined.

\section{Vegetation sampling}

Lines perpendicular to the direction of the slope were set in 2-m intervals from the end of the glacier, and individual plants inside the trim line (Fig. 1) were checked every $2 \mathrm{~m}$. When the first specimen of a species was found, the distance from the glacial foot to that individual was measured.

The positions of the leading edge of each plant species to the foot of the glacier were measured. In August 2011, we were unable to determine the positions of the leading edges of pioneer species because the area in the vicinity of the glacier foot was covered with snow.

A permanent plot $(80 \times 20 \mathrm{~m}$; Fig. 1$)$ was established near the edge of the glacier in August 1996. All herbaceous individuals were mapped in August 1996 and August 2011. Quadrats $(2.5 \times 2 \mathrm{~m})$ for statistical analysis were alternately selected in the permanent plot. 
The number of clumps of Helichrysum citrispinum growing on the upper slope of Tyndall Tarn was surveyed in August 2009 and August 2011. A $30 \times 50$ m permanent plot (Fig. 1) was established in the area with a high population of this species in August 2011. All clumps of this species were mapped within this plot in August 2011.

Statistical methods

Differences in the number of plant clumps and the proportion of plant cover between 1996 and 2011 were examined using t-tests. Bonferroni post-hoc tests were used for comparisons of means among quadrats at different distances from the glacier edge.

A least squares regression model was used to examine the effect of glacial retreat on the rate of movement of the leading edge of each plant species. The effects of variation in temperature on the rate of glacial retreat were also assessed using a least squares regression model.

\section{Results}

Recent changes in temperature and glacial fluctuation at Tyndall Glacier

The Tyndall Glacier has been diminishing rapidly in recent years (Fig. 2), retreating approximately $250 \mathrm{~m}$ from 1958 to 2009 (Fig. 3). The average length of the main axis of the Tyndall Glacier, average width, area, and volume were estimated to be 175 m, 32 m, approximately $5600 \mathrm{~m}^{2}$, and 19,600-22,400 m³ , respectively, in August 2009.

The Tyndall Glacier retreated at a rate of approximately $2.9 \mathrm{~m}_{\text {year }}^{-1}$ from 1958 to 
1997, but the rate increased to $9.8 \mathrm{~m}$ year $^{-1}$ from 1997 to 2002, $14.8 \mathrm{~m}_{\text {year }}{ }^{-1}$ from 2002 to 2006, $8.7 \mathrm{~m}$ year $^{-1}$ from 2006 to 2009, and $7.5 \mathrm{~m} \mathrm{year}^{-1}$ from 2009 to 2011 (Fig. 4).

Monthly mean minimum temperature at Nanyuki (1890 m altitude) on the western base of Mt. Kenya increased by $>2^{\circ} \mathrm{C}$ in 48 years from 1963 to 2011 (Fig. 5). In contrast, precipitation did not significantly decline during the 55-year period starting in 1956, although annual fluctuations did occur (Fig. 6). Monthly mean maximum temperature also increased by $>2^{\circ} \mathrm{C}$ during this period.

The rate of glacial retreat increased with increased monthly mean minimum temperature at $4500 \mathrm{~m}$ in altitude around the study area $\left(\mathrm{y}=5.882 \mathrm{x}+45.427, R^{2}=\right.$ $0.6625 ; P=0.0085)$.

Vegetation succession in relation to recent recession of Tyndall Glacier

The leading edge of Senecio keniophytum followed glacial retreat (Figs. 3, 4) at a rate of approximately $2.9 \mathrm{~m}_{\text {year }}^{-1}$ from 1958 to 1997 . This rate increased to $8.8 \mathrm{~m} \mathrm{year}^{-1}$ from 1997 to 2002, to $14.0 \mathrm{~m}$ year $^{-1}$ from 2002 to 2006, and to $10.3 \mathrm{~m} \mathrm{year}^{-1}$ from 2006 to 2009. The rate of glacial retreat was significantly related to the movement of $S$. keniophytum $\left(\mathrm{y}=0.8635 \mathrm{x}+1.5631, R^{2}=0.7205, P=0.0047\right)$. The movement of Arabis alpina may also have been influenced by the rate of glacial retreat at some level, but this is not significant $\left(R^{2}=0.3273 ; P=0.080\right)$. Other pioneer species, e.g. Agrostis trachyphylla and various mosses and lichens also advanced, and the rates of advance have also increased since 1997 (Fig. 4).

Although changes in the positions of the leading edges of the large woody rosette species Lobelia telekii and Senecio keniodendron were unrelated to glacial retreat 
through 1997, these species have since advanced (Fig. 4).

Vegetation succession in the permanent plot

The vegetation distribution in the permanent plot established near the glacier was measured in August 1996 and August 2011 (Fig. 7). S. keniophytum was only sparsely scattered in the plot in 1996 (Fig. 7a), but its distribution had expanded by 2011 (Fig. 7b). Although 55 clumps of S. keniophytum were found in the sampling quadrats in 1996, this number had increased to 217 clumps in 2011. Six clumps of A. alpina, two of Agrostis trachyphylla, and one of S. keniodendron were also encountered in the sampling quadrats in 2011 (Fig. 7b). Both the average number of plant clumps and the proportion of vegetation cover increased significantly $(P<0.01)$ between 1996 and 2011 (Table 1).

The distance from the edge of Tyndall Glacier significantly affected the number of plant clumps and the proportion of vegetation cover in 1996 (Table 2). The number of plant clumps and the proportion of vegetation cover at 16-18 $\mathrm{m}$ from the glacier's edge were significantly higher than values at 0-14 m (Table 2). We did not observe any plants in quadrats established at distances of $0-8 \mathrm{~m}$ from the edge of the glacier (Fig. 7a).

Similar effects of distance on the number of plant clumps and the proportion of vegetation cover were not observed ( $P>0.05$, respectively) in 2011, when deglaciation exceeded 15 years (Table 3).

Vegetation and land surface stability 
The range in daily temperature around the foot of Tyndall Glacier was around $10^{\circ} \mathrm{C}$ based on data from 31 August to 3 September 2011. During this time, temperatures fell to several degrees below zero by midnight, and temperature ranges were narrower during cloudy days. Ranges in diurnal temperature are generally wide on high-elevation tropical mountains, and freeze-thaw dynamics can render land surfaces unstable due to daily active solifluction. The maximum movement of unstable land surfaces was approximately $4 \mathrm{~m}_{\text {year }}{ }^{-1}$ (32 m over the 8 years from 1994 to 2002) on the Lewis Moraine. This movement was affected by particle sizes of the surface materials and topography (Mizuno 1998, 2005a, 2005b).

Vegetation succession in relation to recent global warming

Although Helichrysu citrispinum had not been found at altitudes above the Tyndall Tarn (4470 m) until 2006, 32 clumps of this species were identified on a lateral moraine of the Lewis Moraine (Fig. 1) on the west-northwest side of Tyndall Tarn above $4470 \mathrm{~m}$ in August 2009 (Fig. 4). This species was not found on the cirque bottom or the talus on the east side. Most of the clumps were blooming in August 2009. In August 2011, 36 of 49 clumps of $H$. citrispinum growing on the slope above Tyndall Tarn were found within the permanent plot $(30 \times 50 \mathrm{~m})$ (Fig. 1$)$, which had been established in an area with a high population of this species (Fig. 8). Only one clump was blooming in August 2011.

The monthly mean maximum temperatures estimated at $4500 \mathrm{~m}$ on Mt. Kenya in 2009 were $11.8^{\circ} \mathrm{C}$ (average from 2007 to $2011: 10.7^{\circ} \mathrm{C}$ ) in March, $10.3^{\circ} \mathrm{C}\left(9.1^{\circ} \mathrm{C}\right.$ ) in April, $9.1^{\circ} \mathrm{C}\left(8.3^{\circ} \mathrm{C}\right)$ in May, $9.6^{\circ} \mathrm{C}\left(8.5^{\circ} \mathrm{C}\right)$ in June, $8.2^{\circ} \mathrm{C}\left(7.3^{\circ} \mathrm{C}\right)$ in July, $8.9^{\circ} \mathrm{C}\left(7.7^{\circ} \mathrm{C}\right)$ 
in August, and $10.1^{\circ} \mathrm{C}\left(8.7^{\circ} \mathrm{C}\right)$ in September. Temperatures from March to September 2009 were about $1^{\circ} \mathrm{C}$ higher than in an average year. $H$. citrispinum normally blooms from December to February. The monthly mean maximum temperature at $4500 \mathrm{~m}$ on Mt. Kenya is normally $<8^{\circ} \mathrm{C}$ from July to November, increasing to $>8^{\circ} \mathrm{C}$ from December, and $H$. citrispinum begins to bloom in December. The temperature in August 2009 was $>8^{\circ} \mathrm{C}$.

Senecio keniodendron rarely blooms, but when it does, it produces buds in mid-December and blooms as temperatures increase from January to February. However, in 2011, many individuals bloomed during August. The difference in temperature between 2011 and the average from 2007 to 2011 was $<1^{\circ} \mathrm{C}$. Precipitation during the dry season from June to August 2011 was much higher than normal. Precipitation in 2011 was 61.7 mm (average from 2002 to 2011: $36.3 \mathrm{~mm}$ ) in June, 126.4 mm (54.7 $\mathrm{mm}$ ) in July, and $100.4 \mathrm{~mm}(68.2 \mathrm{~mm})$ in August. In contrast, precipitation from January to May 2011 was below normal, with values of $6.2 \mathrm{~mm}$ (average from 2002 to 2011: $18.7 \mathrm{~mm})$ in January, $4.1 \mathrm{~mm}(16.9 \mathrm{~mm})$ in February, $42.4 \mathrm{~mm}(54.3 \mathrm{~mm})$ in March, $89.7 \mathrm{~mm}$ (117.1 mm) in April, and $57.8 \mathrm{~mm}$ (71.0 mm) in May.

\section{Discussion}

Vegetation succession in relation to recent global warming

The rate of glacial retreat has accelerated since 1997. The advances of pioneer species such as Senecio keniophytum and Arabis alpina have matched this rate of glacial retreat. 
Seed sizes of S. keniophytum (3mm) and A. alpina (1-1.4mm) are very small, so these species can disperse seeds across relatively extensive area. Seed dispersal ability varies with species and the ability affects the plant community composition (Fuller \& del Moral 2003). The characters of their seed dispersal may facilitate the invasion of these pioneer species in recent deglaciated area. The distributions of mosses, lichens, and Agrostis trachyphylla also advanced. Since 1997, these species advanced at a faster rate than years past as the glacier retreated. S. keniophytum, the first pioneer species to establish after glacial retreat, advanced at a rate similar to that of glacial retreat.

The distance from the glacier edge affects both the number of plant clumps and the proportion of vegetation cover in areas of recent deglaciation. Many seedlings of $S$. keniophytum were likely produced within 5-6 years after deglaciation. However, this effect of distance from the glacier edge was not verified in areas where deglaciation occurred at least 15 years ago. Therefore, the dynamics of plant advancement were substantially affected by the distance from glacier edge (i.e., till age) in areas of recent deglaciation.

The rate of retreat of Tyndall Glacier appears correlated to the increases in monthly mean minimum temperature. The movement of $S$. keniophytum, as well as that of $A$. alpina to some degree, could be explained by the rate of glacial retreat. The recent temperature increase is likely accelerating deglaciation and the expansion of these species onto upper slopes. If the glacier continues to retreat, these species should spread to the summit. Very sparse patches of S. keniophytum already occur around the Point Lenana summit (4985 m) of Mt. Kenya.

Changes in advance at the leading edges of Loberia telekii and Senicio keniodendron, common large woody rosette plants, appeared to be unrelated to glacial retreat up until 
1997; since then, however, these species have advanced upslope. The succession of these species does not appear to be directly related to glacial retreat but may instead be linked to soil development from unstable slope to stable slope, and from poor soil to mature soil through humus deposition by pioneer species in a form of facilitation (Fig. 9).

Rare blooms of S. keniodendron typically occur from January to February. However, in 2011, many individuals bloomed during August. We believe that unusually high precipitation affected blooming during that month.

S. keniodendron is considered a "mast year" species with the masting interval estimated at between 5 and 29 years (Smith \& Young 1982). The interval of masting may explain why the succession of this species does not directly relate to the glacial retreat.

Helichrysum citrispinum was first found on lateral moraines above 4470 m in 2009. During this year, the upper limit of the growing region for these species was estimated at around $4500 \mathrm{~m}$ in altitude. The expansion of $H$. citrispinum was likely favored by the increase of about $1^{\circ} \mathrm{C}$ during the growing season of 2009. In May 1995, four small open-top-chamber (OTC) greenhouses were set up to monitor the phenology and vegetation distribution on Mt. Kisokomagatake (2956 m) in the Central Japanese Alps using the International Tundra Experiment (ITEX) method (Nakashinden et al. 1997; Fukuyo et al. 1998; Zaiki et al. 2003). These OTC experiments demonstrated that such temperature increase can lead to the expansion of some species and to changes in their phenology (Nakashinden et al. 1997; Fukuyo et al. 1998; Zaiki et al. 2003).

Forty-nine clumps of $H$. citrispinum were found on the lateral moraine above $4470 \mathrm{~m}$ (Tyndall Tarn) in 2011. Although the number of clumps in 2011 had increased since 
2009, only one plant had flower buds. Flowering was likely depressed during August because temperatures during 2011 were within a normal cooler range. Carduus platyphyllus was also found above $4470 \mathrm{~m}$. Although these species are not among the pioneers (such as S. keniophytum), they have advanced considerably in recent years. In 2009, the upper limit of the growing regions of these species was estimated at around $4500 \mathrm{~m}$ altitude. We postulated that their range expansions may not be directly related to glacial retreat, but rather their advance to upper slopes may be linked to increases in air temperature. Temperature may be involved because species such as $H$. citrispinum did not emerge on the cirque bottom where the glacier had recently disappeared and where the pioneer species are invading; rather they emerged on the old lateral moraine outside of old glacial flow paths (Figs. 1, 8). Furthermore, decreased movement of the land surface in the lateral moraine probably does not affect species emergence, because the conditions of deposits of comparable size have remained unchanged and movement has been constant (Mizuno 2005a, 2005b). Because the sediment has not changed, it was surmised that soil moisture has also remained constant. This species was not found in study area before 2006, but was in 2009. The annual maximum temperature of study area in 2009 was the highest and $\sim 0.7^{\circ} \mathrm{C}$ higher than the average over 30 years from 1981 to 2011. Therefore, increasing temperature is likely the dynamic triggering of the recent advance of these species.

Environmental conditions affecting the vegetation around Tyndall Glacier

The expansion of pioneer species to higher altitudes is influenced by both glacial retreat and the stability of the land surface (Mizuno 1998, 2005a, 2005b). In the present study, 
areas where seedlings of S. keniodendron and L. telekii were growing in 2009 generally corresponded to the 1958 location of the Tyndall Glacier edge (Fig. 4). Thus, seedlings of these large woody rosette plants are able to grow in areas approximately 50 years after deglaciation (Fig. 9). These locations corresponded to stable land surfaces, with soils that changed over time from a coarse-grained grayish soil to a fine-grained brownish black soil through humus deposition by pioneer species such as $S$. keniophytum (Fig. 9) (Mizuno 1998, 2005a, 2005b). Plant distributions in the alpine zone on Mt. Kenya are significantly affected by movement of the land surface caused by frost action (Mizuno 1998, 2005a, 2005b).

These data indicate that most plants were unable to grow on unstable land surfaces for many years after deglaciation (Fig. 9). If the number of days during which temperatures at midnight fall below zero were to decrease through global warming, frost action would be reduced and vegetation distributions would shift.

\section{Acknowledgments}

We thank Sinichiro Ishikawa (1996), Tatsuhiko Ouchi (1997), Yuichiro Fujioka and Masaaki Ito (2002), Koki Teshirogi and Chisato Yamashina (2006), Mitsuru Hirota (2009), Kosuke Hara (2011), and Simon Karera (1994-2011) for field assistance. We also thank Itsuhiro Hazama and Soichiro Shiraishi of the JSPS Nairobi office; Peter Rauh, Martin Steinbacher of Swiss Federal Laboratories for Materials Science and Technology, and Wataru Morishima of Nihon University for their meteorological assistance; and Takaaki Tanaka for designing the figures. The expenses for field 
research were provided by a Grant-in-Aid for Scientific Research (Project Nos. 13371013, 17251001, and 23657020) from the Ministry of Education, Science, Sports and Culture of Japan and Mitsui \& Co., Ltd., Environment Fund 2007.

\section{References}

Bhatt, N. 1991. The geology of Mount Kenya. In Allen I. (ed.) Guide to Mount Kenya and Kilimanjaro, pp. 54-66. The Mountain Club of Kenya, Nairobi.

Caccianiga, M., Andreis, C. \& Cerabolini, B. 2001. Vegetation and environmental factors during primary succession on glacier forelands: some outlines from the Italian Alps. Plant Biosystems 135: 295-310.

Caccianiga, M. \& Andreis, C. 2004. Pioneer herbaceous vegetation on glacier forelands in the Italian Alps. Phytocoenologia 34: 55-89.

Charnley, F. E. 1959. Some observations on the glaciers of Mount Kenya. Journal of Glaciology 3: 483-492.

Coe, M. J. 1967. The Ecology of the Alpine Zone of Mt. Kenya. Dr. W. Junk Publishers, Hague.

Fukuyo, S., Kurihara, M., Nakashinden, I., Kimura, K., Iijima, Y., Kobayashi, Y., Masuzawa, T., Yamamoto, S., Morimoto, M., Kouyama, T., Kobayashi, S. Yamamoto, T., Mizuno, K. \& Machida, H. 1998. Short-term effects of wind shield on phenology and growth of alpine plants in Mount Kiso-Komagatake, center Japan. Proceedings of the NIPR symposium on Polar Biology 11: 147-158.

Fuller R. N. \& del Moral, R. 2003. The role of refugia and dispersal in primary 
succession on Mount St. Helens, Wasgington. Journal of Vegetation Science 14: 637-644.

Garbarino, M., Lingua, E., Nagel, T. A., Godone, D. \& Motta, R. 2010. Patterns of larch establishment following deglaciation of Ventina glacier, central Italian Alps. Forest Ecology and Management 259: 583-590.

Hastenrath, S. 1983. Diurnal thermal forcing and hydrological response of Lewis Glacier, Mount Kenya. Archiv fur Meteorologie Geophysik und Bioklimatologie, Ser. A 32: 361-373.

Hastenrath, S. 1984. The Glaciers of Equatorial East Africa. Reidel, Dordrecht. Hastenrath, S. 1991. The climate of Mount Kenya and Kilimanjaro. In: Allen, I. (ed.) Guide to Mount Kenya and Kilimanjaro, pp. 54-66. The Mountain Club of Kenya, Nairobi.

Hastenrath, S. 1997. Glacier recession on Kilimanjaro, East Africa, 1912-1989. Journal of Glaciology 43: 455-459.

Hastenrath, S. 2005. Glaciological studies on Mount Kenya 1971-2005. University of Wisconsin, Madison.

Hastenrath, S. 2008. Recession of equatorial glaciers: a photo documentation. Sundog Publishing, Madison.

Hastenrath S., Rostom R. \& Caukwell, R. 1989. The glaciers of Mount Kenya, scale 1:5,000, SK 120. Survey of Kenya, Nairobi.

Hedberg, O. 1951. Vegetation belts of East African Mountains. Svensk Botanisk Tidskrift 45: 140-195.

Hedberg, O. 1964. Features of Afroalpine plant ecology. Acta Phytogeographica Suecica 49: 1-144. 
Hedberg, O. 1968. Taxonomic and ecological studies on the afroalpine flora of Mt. Kenya. Hochgebirgsforschung 1: 171-194.

Hodkinson, I. D., Coulson S. J. \& Webb N. R. 2003. Community assembly along proglacial chronosequences in the high Arctic: vegetation and soil development in north-west Svalbard. Journal of Ecology 91: 651-663.

Jones, C. \& del Moral, R. 2005. Patterns of primary succession on the foreland of Coleman Glacier, Washington, USA. Plant Ecology 180:105-116.

Kruss, P. D. \& Hastenrath, S. 1983. Variation of ice velocity at Lewis Glacier, Mount Kenya: Verification midway into a forecast. Journal of Glaciology 29: 48-54.

Mahaney, W. C. 1984. Late glacial and post glacial chronology of Mount Kenya, East Africa. Palaeoecology of Africa 16: 327-341.

Mahaney, W. C. 1989. Quaternary glacial geology of Mount Kenya. In: Mahaney W. C. (ed.) Quaternary and Environmental Research on East African Mountains, pp. 121-140. Balkema, Rotterdam.

Mahaney, W. C. 1990. Ice on the Equator: Quaternary Geology of Mount Kenya. Wm Caxton Ltd, Sister Bay.

Mahaney, W. C. \& Spence, J. R. 1989. Lichenometry of Neoglacial moraines in Lewis and Tyndall cirques on Mount Kenya. Zeitshrift für Gletscherkunde und Glazialgeologie 25: 175-186.

Matthews, J. A. 1992. The Ecology of recently-deglaciated terrain. a geoecological approach to glacier forelands and primary succession. Cambridge University Press, Cambridge.

Mizuno, K. 1998. Succession processes of alpine vegetation in response to glacial fluctuations of Tyndall Glacier, Mt. Kenya, Kenya. Arctic and Alpine Research 30: 
340-348.

Mizuno, K. 2005a. Glacial Fluctuation and Vegetation Succession on Tyndall Glacier, Mt. Kenya. Mountain Research and Development 25: 68-75.

Mizuno, K. 2005b. Vegetation Succession in Relation to Glacial Fluctuation in the High Mountains of Africa, African Study Monographs, Supplementary Issue 30: 195-212. Mori, A. S., Osono, T., Uchida, M. \& Kanda, H. 2008. Changes in the structure and heterogeneity of vegetation and microsite environments with the chronosequence of primary succession on a glacier foreland in Ellesmere Island, high arctic Canada. Ecological Research 23: 363-370.

Nagy, L. \& Grabherr, G., 2009. The Biology of Alpine Habitats. Oxford University Press, New York.

Nakashinden, I., Masuzawa, T., Fukuyo, S., Kimura, K., Yamamoto, S., Iijima, Y., Mizuno, K., Kobayashi, S., Yamamoto, T., Machida, H. \& Takaoka, S., 1997. A preliminary report on phenological monitoring using experimental chambers in Mt. Kisokomagatake, Central Japan. Proceedings of the NIPR symposium on Polar Biology 10: 196-204.

Niederfriniger-Schlag, R. \& Erschbamer, B. 2000. Germination and establishment of seedlings on a glacier foreland in the Central Alps. Arctic, Antarctic and Alpine Research 32:270-277.

Okitsu, S., Sawaguchi, S., Hasegawa, H. \& Kanda, H., 2004. Vegetation development on the glacier moraines in Oobloyah Valley, Ellesmere Island, high arctic Canada. Polar Bioscience 17: 83-94.

Raffl, C. \& Erschbamer, B. 2004. Comparative vegetation analyses of two transects crossing a characteristic glacier valley in the Central Alps. Phytocoenologia 34: 
$225-240$.

Raffl, C., Mallaun, M., Mayer, R. \& Erschbamer, B., 2006a. Vegetation Succession Pattern and Diversity Changes in a Glacier Valley, Central Alps, Austria. Arctic, Antarctic, and Alpine Research 38(3): 421-428.

Raffl, C., Schönswetter, P. \& Erschbamer, B. 2006b. 'Sax-sess’ - genetics of primary succession in a pioneer species on two parallel glacier forelands. Molecular Ecology 15: $2433-2440$.

Rehder, H. 1992. Die Vegetation des Mount Kenya. Naturwissenschaften 79: 492-498.

Rehder, H., Beck, E. \& Kokwaro, J. O. 1988. The afroalpine plant communities of Mt. Kenya (Kenya). Phytocoenologia 16: 433-463.

Robbins, J. A. \& Matthews, J. A. 2009. Pioneer vegetation on glacier forelands in southern Norway: emerging communities?. Journal of Vegetation Science 20: 889-902.

Smith, A. P. \& Young, T. P. 1982. The cost of reproduction in Senecio keniodendron, a giant rosette species of Mt. Kenya. Oecologia 55: 243-247.

Smith, A. P. and Young, T. P. 1987. Tropical alpine plant ecology. Annual Review of ecology and Systematics 18: 137-158.

Spence, J. R. 1989. Plant succession on glacial deposits of Mount Kenya, East Africa. In: Mahaney W. C. (ed.) Quaternary and Environmental Research on East African Mountains, pp. 279-290. Balkema, Rotterdam.

Spence, J. R. \& Mahaney W. C. 1988. Growth and ecology of Rhizocarpon section Rhizocarpon on Mount Kenya, East Africa. Arctic and Alpine Research 20: 237-242. Troll, C., and Wien K. 1949. Der Lewis Gletscher am Mount Kenya. Geografiska Annaler 31: 257-274. 
Tscherko, D., Rustemeier, T. R. A., Wanek, W. \& Kandeler, E. 2003. Functional diversity of the soil microflora in primary succession across two glacier forelands in the Central Alps. European Jouranal of Soil Science 54: 685-697.

Whittaker, R. J. 1987. An application of detrended correspondence analysis and non-metric multidimensional scaling to the identification and analysis of environmental factor complexes and vegetation structures. Journal of Ecology 75: 363-376.

Young, T. P. 1991. The ecology, flora and fauna of Mount Kenya and Kilimanjaro. In: Allan, I. (ed.) Guide to Mount Kenya and Kilimanjaro. The Mountain Club of Kenya, Nairobi.

Young, T. P. \& Peacock, M. M. 1992. Giant senecio and alpine vegetation of Mount Kenya. Journal of Ecology 80: 141-148.

Zaiki, M., Tukada, Y., Fukuyo, S. \& GENET. 2003. Change in alpine plant distribution during artificial warming experiment at Kisokomagatake, central Japan. Theory and applications of GIS 11(2): 23-31. (In Japanese with English abstract.)

Fig. 1. Geomorphological map of the environs of Tyndall Glacier, Mt. Kenya. Margins of Tyndall Glacier in 1919 and 1926 are from Hastenrath (1983). The Lewis Moraine (Lewis Till) and the Tyndall Moraine (Tyndall Till) are from Mahaney (1990) and Mahaney and Spence (1989). The map is by Kazuharu Mizuno, based on Hastenrath et al. (1989).

Fig. 2. Tyndall Glacier in 1992 (a), 1997 (b), 2002 (c), 2006 (d), 2011 (e). 
Fig. 3. Positions of the Tyndall Glacier front and the leading edge (upper distribution limit) of Senecio keniophytum, on the topographic profile.

Fig. 4. Glacial fluctuations and succession of alpine plants. Horizontal axis: distance (m) from the margin of the Tyndall Glacier to the leading edge (upper distribution limit) of each plant species. Vertical axis: date (the length of the vertical axis indicates years). Arrow: movement of the glacial margin or the leading edge of each plant species (the inclination of the arrow indicates speed of movement).

Fig. 5. Monthly mean minimum temperatures (a) and annual mean minimum temperature (b) at 1890 m (0.03 N, 37.02 E) on the Nanyuki side of Mt. Kenya.

Fig. 6. Precipitation at 1890 m (0.03 N, 37.02 E) on the Nanyuki side of Mt. Kenya.

Fig. 7. Vegetation distribution in 1996 (a) and 2011 (b) in a permanent plot $(80 \mathrm{~m} \times 20$ m) established close to the foot of the glacier in August, 1996. Patch without letters: Senecio keniophytum; A: Arabis alpina; T: Agrostis trachyphylla; S: Senecio keniodendron.

Fig. 8. Distribution of the clumps of Helichrysum citrispinum in a permanent plot $(30 \mathrm{~m}$ $\times 50 \mathrm{~m})$ established in the area with the high population in August 2011.

Fig. 9. Typical soil profiles and till ages (years after the disappearance of the glacier). Till ages (years) of the plots are estimated from glacial retreat rates [3.8m/yr $(-1958)$ (Charnley, 1959); 2.9m/yr (1958-1997); 9.8m/yr (1997-2002); 14.8m/yr (2002-2006); 8.7m/yr (2006-2009)] and distances from the ends of the glaciers. They were determined using soil profile data observed in 1992-2009.

Table 1. The average number of plant clumps (N) and the average proportion of vegetation cover (RC; \%) on 80 quadrats $(2.5 \mathrm{~m} \times 2 \mathrm{~m})$ in 1996 and 2011.

Table 2. The average number of plant clumps (N) and the average proportion of 
vegetation cover $(\mathrm{RC}$; \%) in quadrats $(2.5 \mathrm{~m} \times 2 \mathrm{~m})$ based on the distance $(\mathrm{m})$ from the end of glacier in 1996.

Table 3. The average number of plant clumps $(\mathrm{N})$ and the average proportion of vegetation cover $(\mathrm{RC}$; \%) in quadrats $(2.5 \mathrm{~m} \times 2 \mathrm{~m})$ based on the distance $(\mathrm{m})$ from the end of glacier in 2011.

Table 1. The average number of plant clumps $(\mathrm{N})$ and the average proportion of vegetation cover (RC; \%) on 80 quadrats $(2.5 \mathrm{~m} \times 2 \mathrm{~m})$ in 1996 and 2011.

\begin{tabular}{|c|c|c|}
\hline & $\mathrm{N}$ & $\mathrm{RC}(\%)$ \\
\hline 1996 & $0.2 \pm 0.1$ & $0.0 \pm 0.1$ \\
\hline 2011 & $2.7 \pm 0.3$ & $3.6 \pm 0.5$ \\
\hline & $P<0.01$ & $P<0.01$ \\
\hline
\end{tabular}

Table 2. The average number of plant clumps $(\mathrm{N})$ and the average proportion of 
vegetation cover $(\mathrm{RC}$; \%) in quadrats $(2.5 \mathrm{~m} \times 2 \mathrm{~m})$ based on the distance $(\mathrm{m})$ from the end of glacier in 1996.

\begin{tabular}{|l|l|l|l|l||}
\hline $\mathrm{m}$ & $\mathrm{N}$ & $\mathrm{RC}(\%)$ & \\
\hline $0-2$ & $0.0 \pm 0.0 \mathrm{a}$ & $0.0 \pm 0.0 \mathrm{a}$ & \\
\hline $4-6$ & $0.0 \pm 0.0 \mathrm{a}$ & $0.0 \pm 0.0 \mathrm{a}$ & \\
\hline $8-10$ & $0.1 \pm 0.1 \mathrm{a}$ & $0.0 \pm 0.0 \mathrm{a}$ & & \\
\hline $12-14$ & $0.1 \pm 0.1 \mathrm{a}$ & $0.0 \pm 0.0 \mathrm{a}$ \\
\hline $16-18$ & $0.6 \pm 0.2 \mathrm{~b}$ & $0.1 \pm 0.0 \mathrm{~b}$ & \\
\hline \multicolumn{2}{|l|}{ Different letters indicate statistically significant differences at the $P<0.001$ level. } \\
\hline
\end{tabular}

Table 3. The average number of plant clumps $(\mathrm{N})$ and the average proportion of vegetation cover $(\mathrm{RC}$; \%) in quadrats $(2.5 \mathrm{~m} \times 2 \mathrm{~m})$ based on the distance $(\mathrm{m})$ from the end of glacier in 2011.

\begin{tabular}{|c|c|c|}
\hline $\mathrm{m}$ & $\mathrm{N}$ & RC (\%) \\
\hline $0-2$ & $2.3 \pm 0.4$ & $5.4 \pm 1.6$ \\
\hline $4-6$ & $3.0 \pm 0.6$ & $2.6 \pm 0.5$ \\
\hline $8-10$ & $2.4 \pm 0.5$ & $2.3 \pm 0.5$ \\
\hline $12-14$ & $2.7 \pm 0.8$ & $3.4 \pm 1.1$ \\
\hline $16-18$ & $3.3 \pm 0.5$ & $4.4 \pm 1.0$ \\
\hline
\end{tabular}




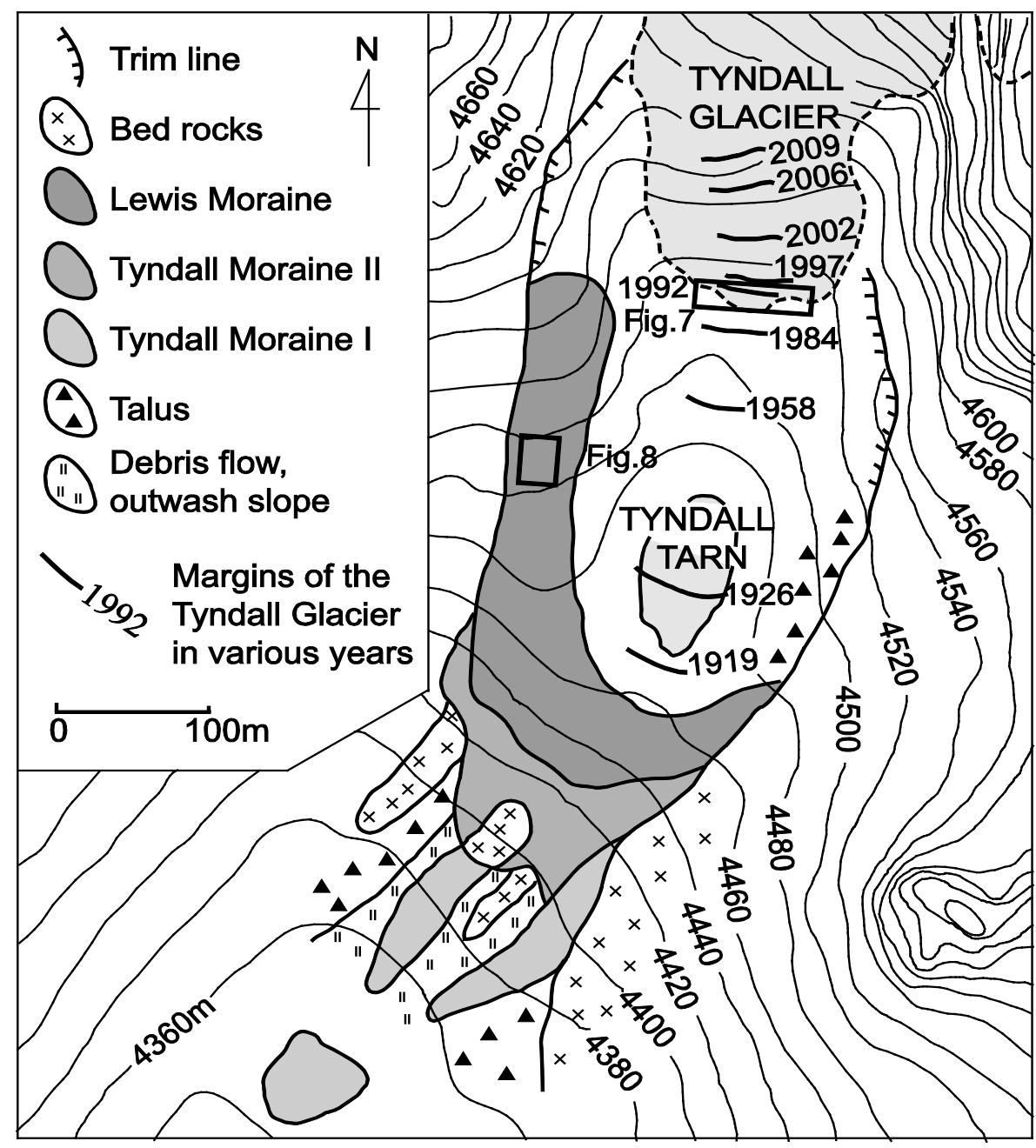




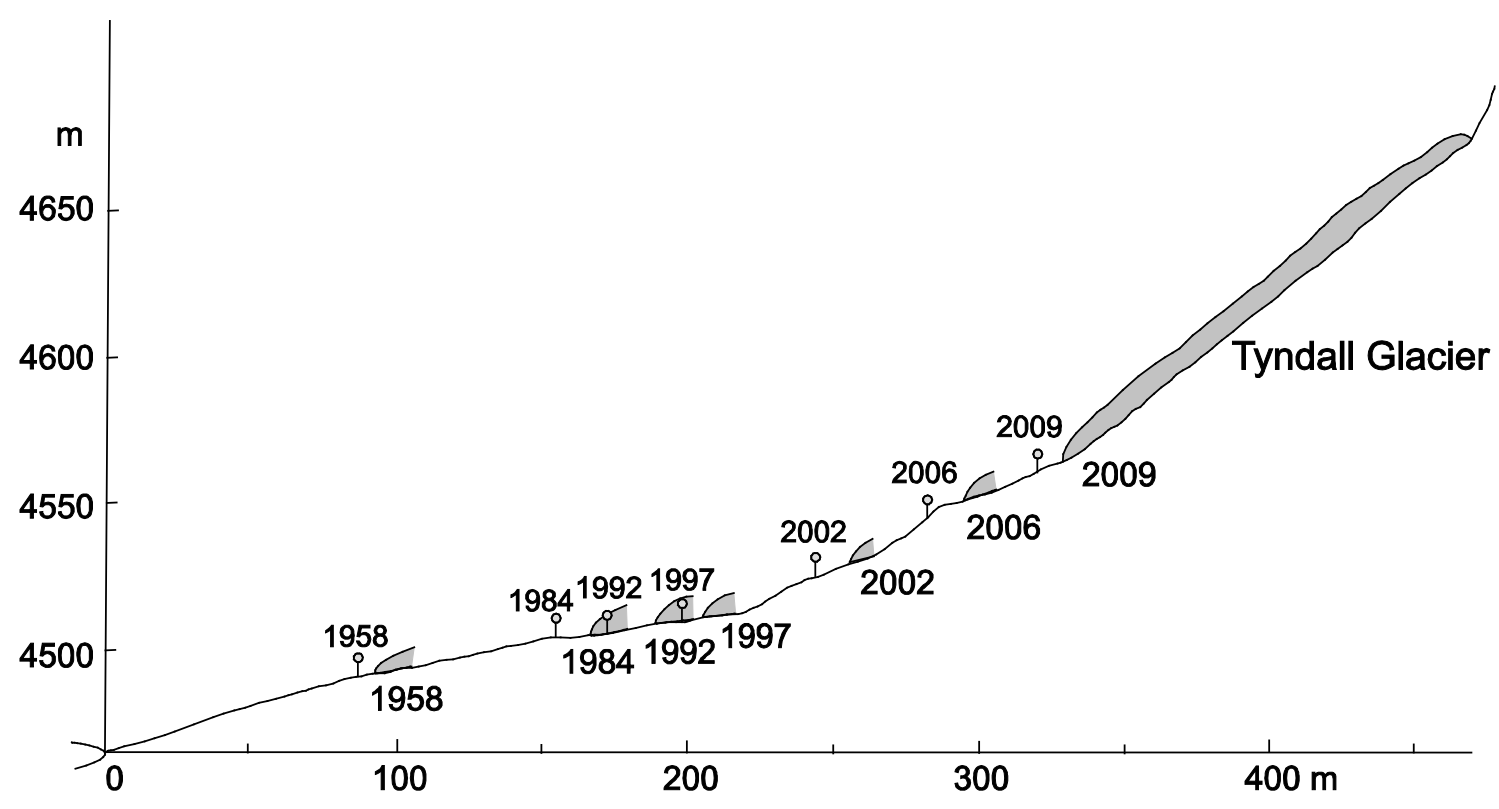

Tyndall Tarn

Fig. 3 


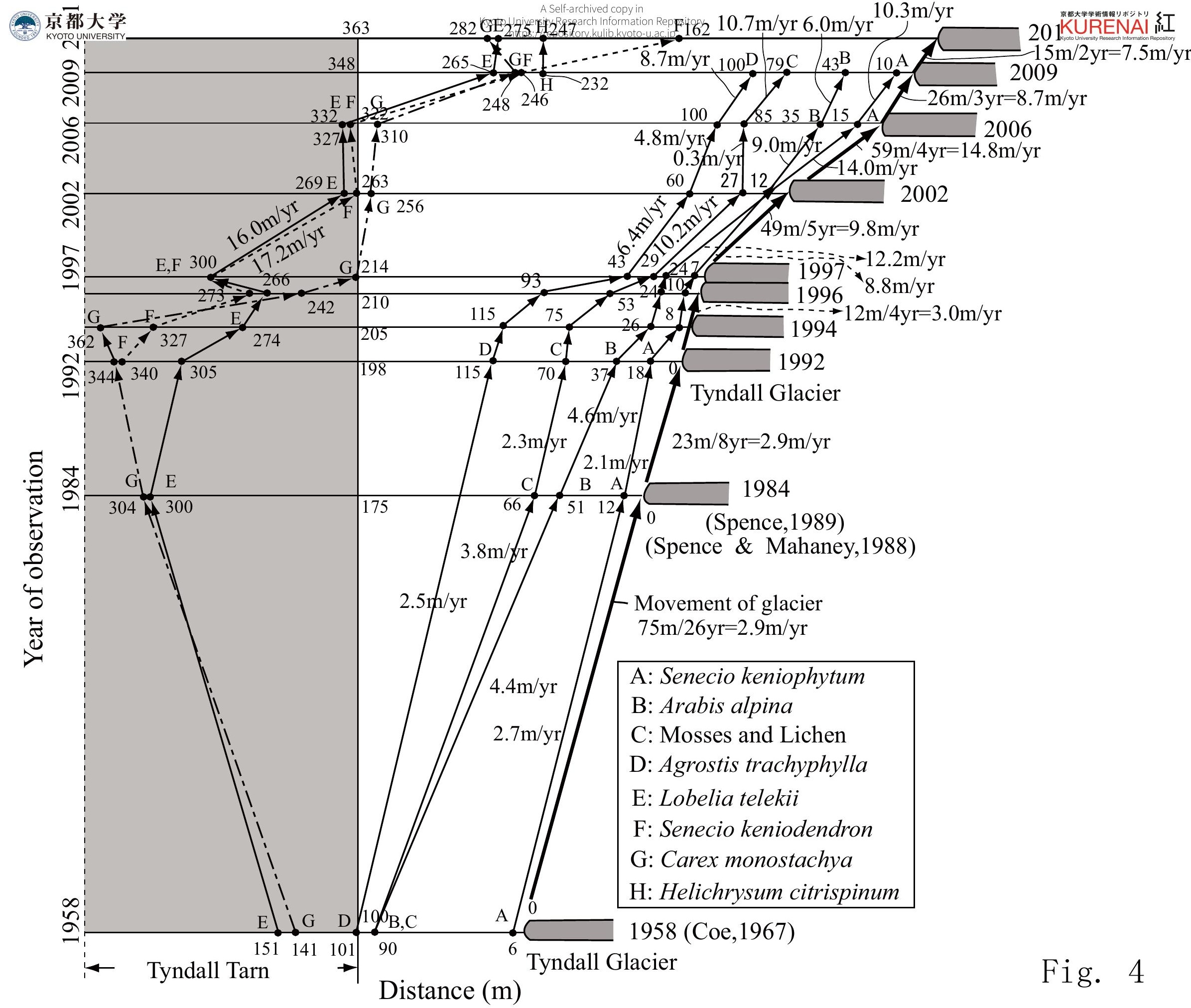



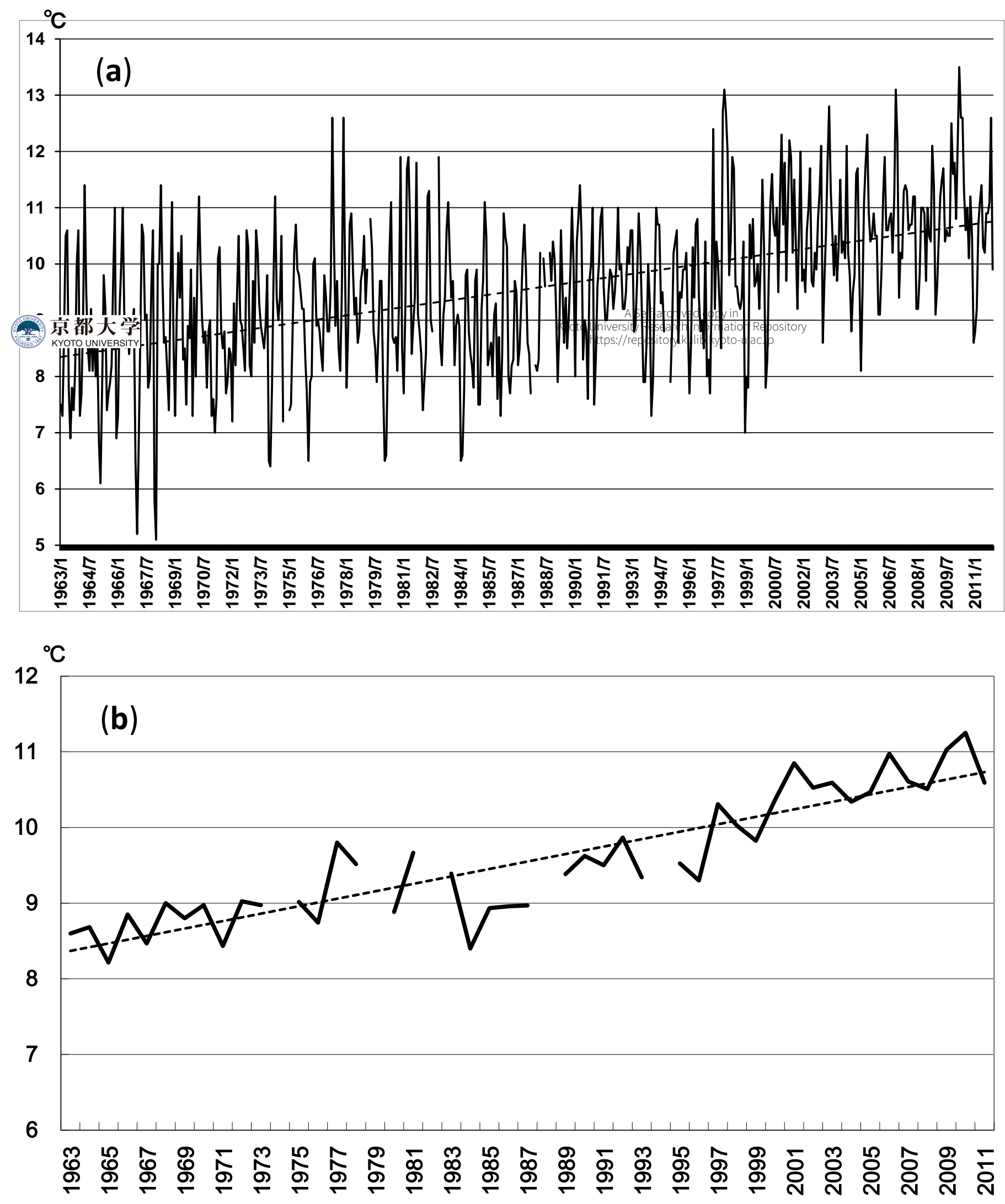

Fig. 5 


\section{$\mathrm{mm}$}

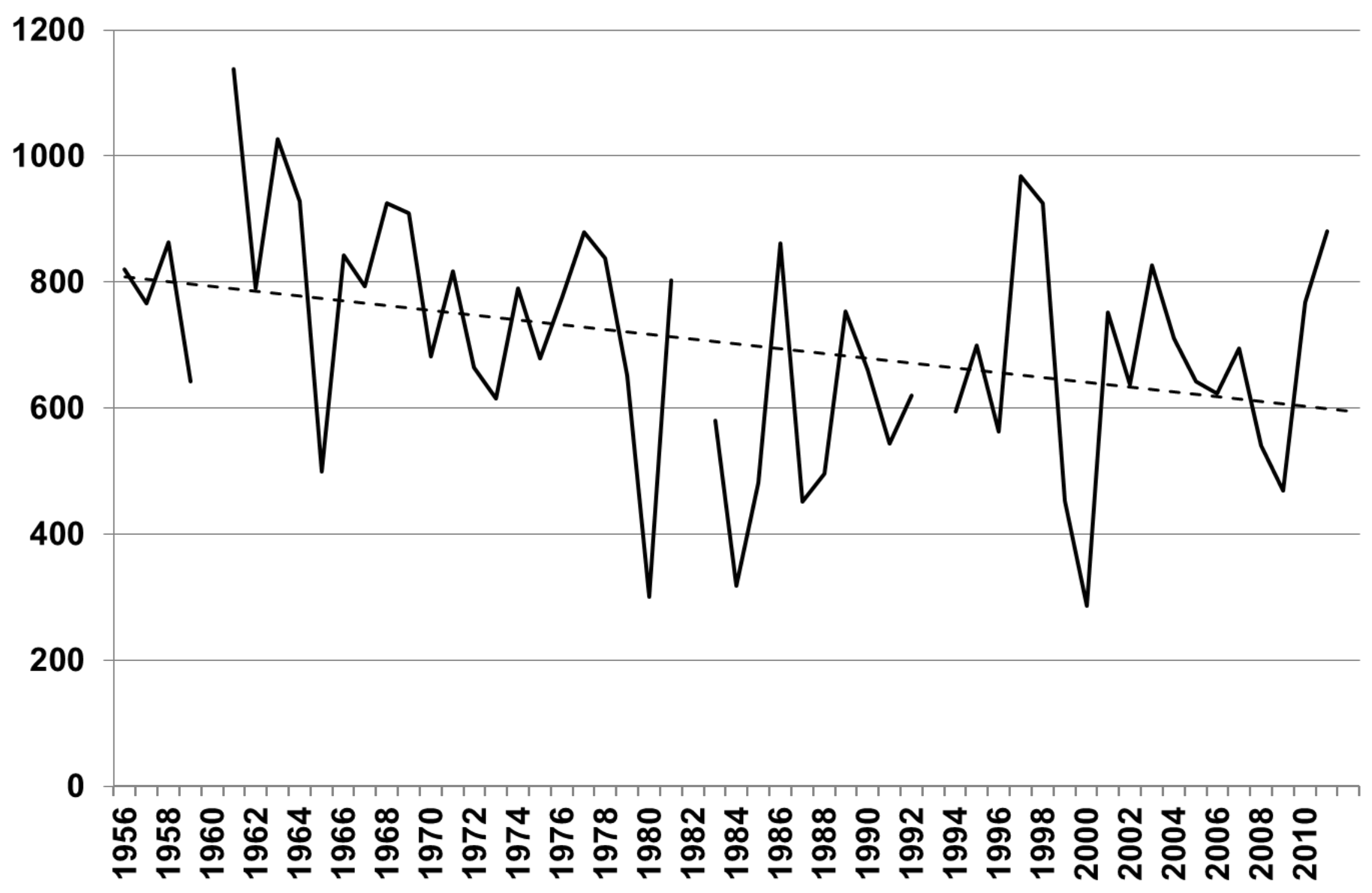

Fig. 6 


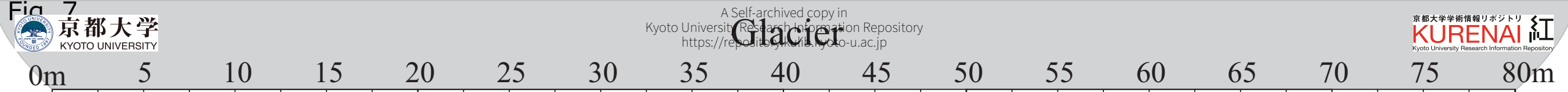

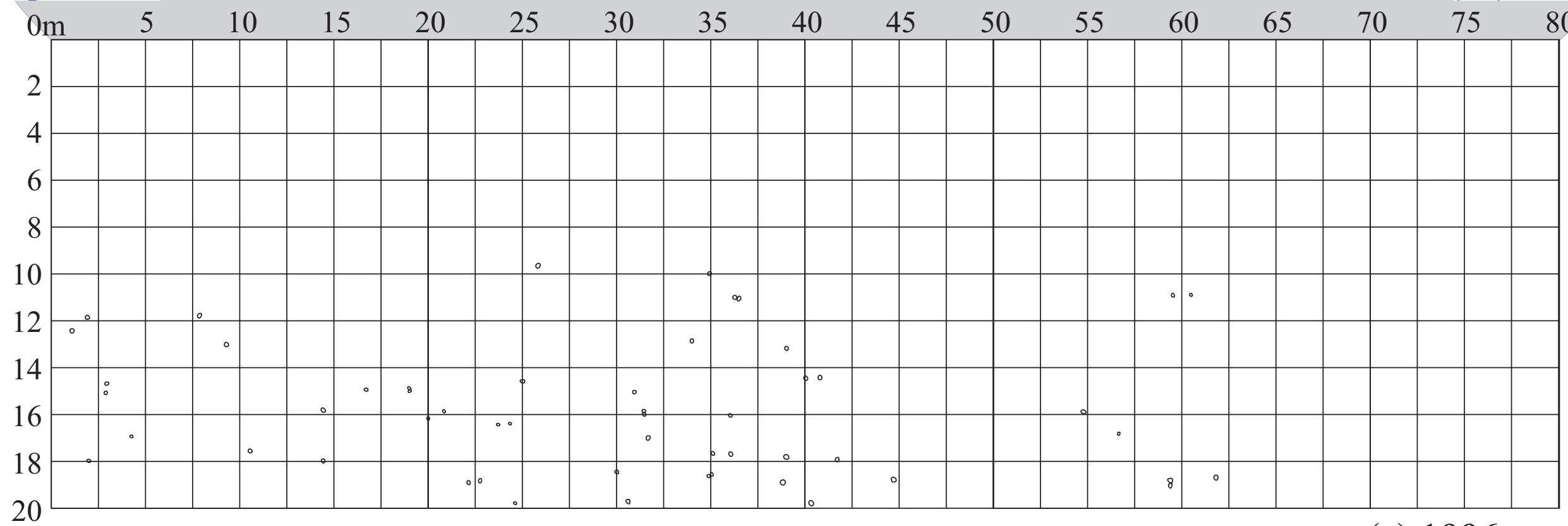

(a) 1996

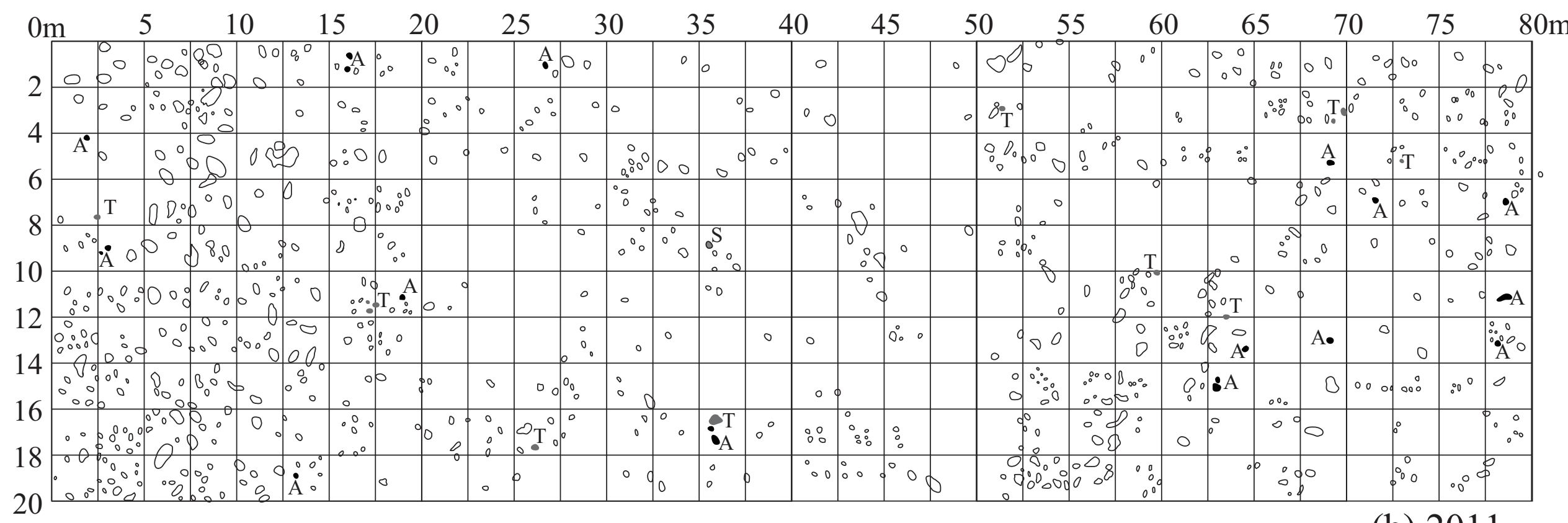

(b) 2011 


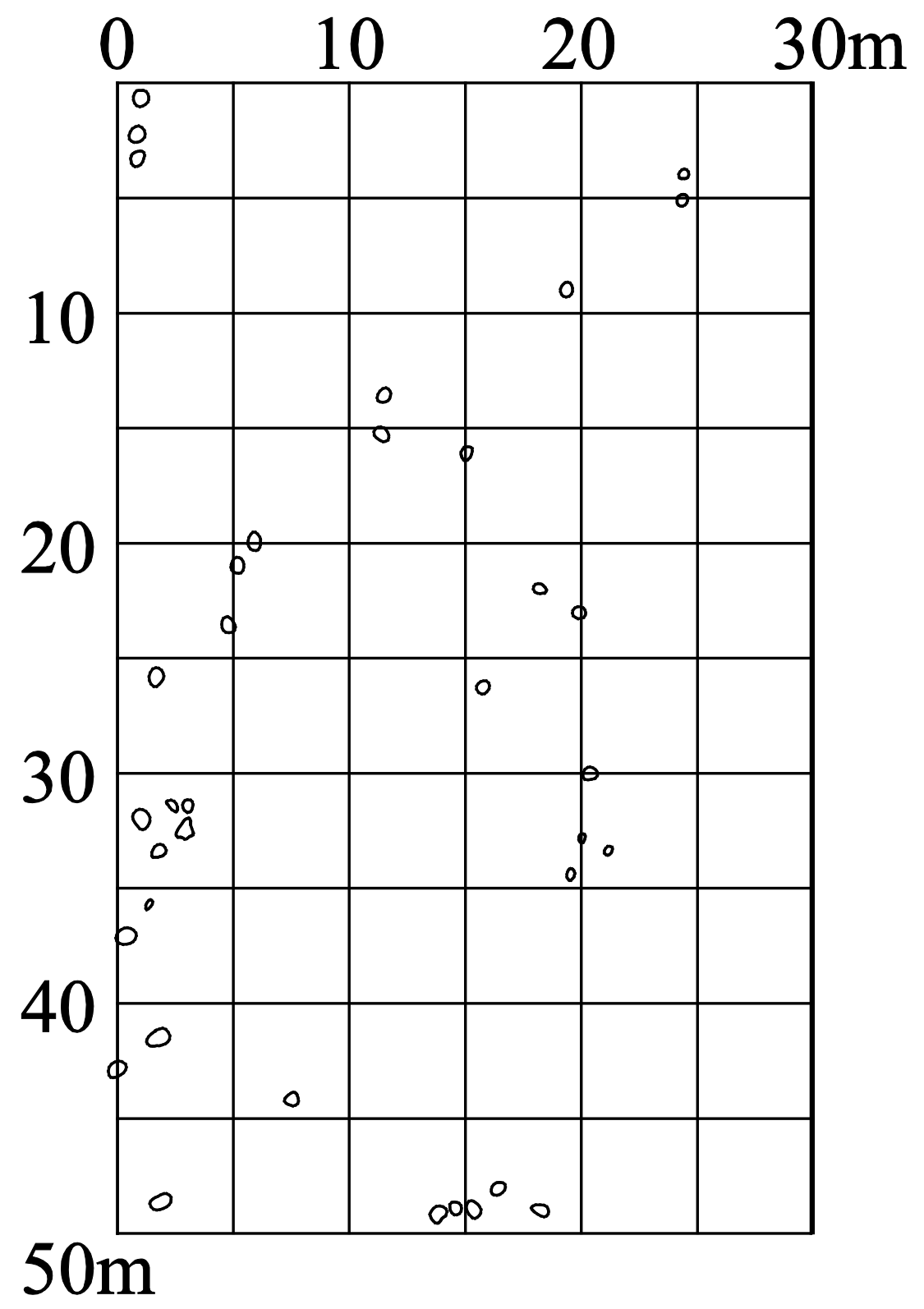

Fig. 8 